\title{
Impact of Corporate Governance on the Effectiveness of Accounting Information System in Jordanian Industrial Companies
}

\author{
Feras Izzat Oqlah Kasasbeh ${ }^{1}$ \\ ${ }^{1}$ Assistant Professor, Administrative Sciences Department, Community College, University of Tabuk, KSA \\ Correspondence: Feras Izzat Oqlah Kasasbeh, Assistant Professor, Administrative Sciences Department, \\ Community College, University of Tabuk, KSA.
}

Received: July 28, 2017

doi:10.5539/ibr.v10n10p1
Accepted: August 15, $2017 \quad$ Online Published: August 31, 2017

URL: https://doi.org/10.5539/ibr.v10n10p1

\begin{abstract}
In this study, the impact of corporate governance factors on the effectiveness of accounting information system has been investigated considering Jordanian Industrial Companies. Authors considered the influence of corporate governance factors such as organisational vision, and goal translation, data-driven decision making, expertise and experience of governing committee, KPI based performance evaluation and effective collaboration between leaders and departments on the effectiveness of accounting information system. The effectiveness of accounting information system has been measured by the ease of use, security, storage, it's usability for delivery and decision making. The secondary data was collected using a questionnaire from 30 accounting firms in Jordan. Specialised software called Statistical Package for the Social Sciences (SPSS) has been used to analyse the data gathered and draw conclusions. Authors found that AIS is an effective tool for decision making and performance evaluation when management adopts the data-driven approach. However, for an effective AIS, it must be governed by subject matter experts who have expertise and experience is financial and accounting methodologies. Authors emphasised on the role of the leadership team in creating a clear vision and ASMART goals so that the AIS system can be aligned and help the departments to deliver on targets. It was observed that effective communication, collaboration among the leaders and departments significantly influence the effectiveness of AIS structure and it's ability to deliver results.
\end{abstract}

Keywords: Accounting information system (AIS), corporate governance (CG), Management information system (MIS), key performance indicator (KPI)

\section{Introduction}

Many organisations in different countries around the world seek to establish effective account information systems to meet organisational goals and be competitive. But to get the most out of it the system need to be supported by organization's corporate governance strategy. The concept and practice of well organised corporate governance are in action in developed countries who have strong economic structure. These countries seek to rip the full benefit of a structured accounting information system by collaborating their corporate strategy with the system's capability and deliver promised results. The world has seen several business collapses and scandals related to accounting frauds and therefore became wiser and cautious. Therefore, to prevent recurrence of such incidents acknowledged the importance of structured accounting information system. However, the success of such a system is dependent on several factors internal to the organisations. The mission, vision, transformation and translation of business goals play a vital role and define usability of the Endeavour. In this era of globalisation, companies seek to expand their scope, as many countries went global scale and joined World Trade Organization and European conventions to establish free trade with many other countries. The expansion of scope not only creates a lot of opportunities but also develops a need for careful management of associated risks. To make this work the organisations need to establish a proper corporate governance mechanism. This study seeks to recreate and explore the concept for Jordanian accounting firms and investigate the effect of corporate governance on company's AIS system. By the end of the analysis, authors hope to make recommendations that helps one understand how corporate governance policies determine the success of AIS based on the data gathered. This is expected to illustrate how going forward Jordanian organisations can develop a culture of effective corporate governance system to maximise the effectiveness of AIS. A well thought and managed AIS system helps the organisation to deliver on organization's business strategies and improves its performance (Chenhall, 2003). 


\section{Research Problems}

1. How organisations vision and goal translation influence the effectiveness of organization's account information system?

2. How have the data-driven decision making and performance evaluation influenced the effectiveness of organization's account information system?

3. How the expertise and experience of governing committee influence the effectiveness of organization's account information system?

\section{Corporate Governance in Jordan}

The term corporate governance illustrates a system that determines rights and responsibilities among senior management, junior management, shareholders and other stakeholders. A company's corporate governance determines it's rules and procedures for making strategic decisions to meet preset goals. It helps an organisation to develop AMSART goals from its vision and steer it's activities accordingly to reach the targets. In recent years the importance of well-established corporate governance has drawn the attention of many in Jordan because of the initiative of the World Bank (Marashdeh, 2014). Initiatives have been taken and a national team of consultants has been formed to investigate the legislative environment in Jordan. Jordanian organisations are becoming keen to understand and establish the rules and standards of International Corporate Governance (Al-jazi, 2007). This study aims at exploring the key corporate governance features in Jordanian organisations. Company's corporate governance policies include but not limited to, the leadership visions and the meaningful translation of goals, accounting and auditing standards and the expertise of governing committee, evaluation standards, decision making approaches, and effective collaboration among leaders and departments. The corporate standards determine the roles and responsibilities of senior and junior management bodies and the guidelines to be followed for accelerated delivery and performance (Almasarwah, 2015).

\section{Accounting Information Systems}

Accounting Information System can be defined as a systematic approach to assist management plan, monitor and control the organization's economic activity and help in decision making. Such a system is well integrated and focused on a set of objectives (Watts, 1999).

Accounting Information System shapes the governance of economic-financial area of an organisation.

As per FASB (1980), the first and foremost goal of accounting is to help decision makers by providing them with useful information. Globalisation and technological advancement have created the need for establishing and using accounting information from a strategic viewpoint (El Louadi, 1998). Being a part of management information system (MIS), AIS collects, classifies, analyses, stores and provides financial information to senior and junior management bodies for decision making (Moscove \& Simkin, 1982). Researchers acknowledged the importance and effectiveness of such a system for all organisations (Curtis, 1995; Borthick and Clark, 1990; Rahman et al., 1988; Wilkinson, 1993; Wilkinson et al., 2000). Romney \& Steinbart (2006) identified six interrelated components for AIS such as people, procedures and instructions, data, software, information technology infrastructure, and internal controls and security measures. Gordon \& Seller (1984) acknowledged AIS is one of the core systems in an organisation which is vital to every department and functions and helps effective decision making. Previous researchers illustrated the impact of AIS in strategic management, and managing of strategic priorities (Ittner and Larcker, 1997; Bouwens and Abernethy, 2000). For effective decision making, information should be relevant and faithful represented (Rankin, Stanton, McGowan, Kimberly \& Tilling, 2012, 35). Relevance illustrates economic constructs such as fair value, historical cost etc. which assists user's decision (Kadous, Koonce \& Thayer, 2012). Faithful representation indicates the adequacy of measurement of the economic construct (Kadous, Koonce \& Thayer, 2012). Researchers claimed that success of strategic advantage is an outcome of well managed Accounting Information Systems (AIS) (Langfield-Smith, 1997).

\section{Relationship between Accounting Information Systems and Organizational Effectiveness}

Bolon, (1998), emphasised that a well-structured AIS will definitely assist in the decision making and determine future steps. The system will help it's users to better understand and differentiate between various scenarios (Bolon, 1998). Previous studies showed that AIS is significantly related to the effectiveness of organisations (Ponemon and Nagida, 1990). They acknowledged the importance of AIS in effective decision making (Bolon, 1998). Bolon (1998) illustrated in his work that accounting information system has its impacts on effective decision making, performance evaluation, internal controls and regular financial activities. Accounting information is the lifeblood of a business and determines it's course of action. Organizations must adopt 
data-driven decision making to have a competitive advantage and to be able to use its resources better. Hunton, (2002) also found a strong relationship between accounting information system and organisational effectiveness, in his work.

\section{Research Model and Hypotheses}

Considering the triple constraints i.e. scope, time and cost, the authors kept the model comparatively simple and considered the following corporate governance factors as predictors of the success of AIT system in these companies:

1. Management's practice of data-driven approach in decision making

2. SME governed accounting system

3. Governing committee's knowledge and experience in finance and accounting

4. Leadership teams' vision, it's translation and alignment with business goals

5. KPI based performance evaluation

6. Effective collaboration and strategic discussion about company policies

AIS must fit with organisational decision-making requirements for information communication and control (Nicolaou, 2000). The authors considered four vital factors that explain the effectiveness of firm's accounting information system.

1. Ease of use and effectiveness of AIS in decision making

2. Effective security and management of AIS

3. Usability and importance of AIS for departmental delivery and performance evaluation

4. Effective storage and recall system of AIS data and it's alignment with business goals

\subsection{Hypotheses}

From the study of literature and previous works in the similar field, the authors developed the following hypotheses to investigate the influence of corporate governance on the effectiveness of accounting information system in an organisation.

H1: Management's practice of data-driven approach in decision making influences ease of use and effectiveness of AIS in decision making

H2: SME governed accounting system influences ease of use and effectiveness of AIS in decision making

H3: Governing committee's knowledge and experience in finance and accounting influences effective security and management of AIS

H4: Leadership teams' vision, it's translation and alignment with business goals influences effective security and management of AIS

H5: KPI based performance evaluation influences effective security and management of AIS

H6: Management's practice of KPI based evaluation influences usability and importance of AIS for departmental delivery and performance evaluation

H7: SME governed accounting system influences usability and importance of AIS for departmental delivery and performance evaluation

H8: Leadership team's vision, translation and their alignment with business goals influences effective storage and recall system of AIS data and it's alignment with business goals

H9: Governing committee's knowledge and experience in finance and accounting influences storage and recall system of AIS data and it's alignment with business goals

H10: Effective collaboration and strategic discussion about company policies influence storage and recall system of AIS data and it's alignment with business goals

\section{Research Methodology}

The study included participants from Jordanian accounting firms that are listed on the Amman Financial Market. The authors focused on exploring the implication of an empirical concept within companies that have been using AIS computer based system and standard corporate governance policies. The survey respondents were permanent junior and senior management stuff who have at least a year of experience in the respective 
companies. The questionnaire has been kept very brief and on point. The study focused on gathering primary and secondary data. The authors conducted a detailed review of relevant literature i.e. published research papers, theories, and internet discussion blogs for a secondary source of information. A survey questionnaire has been administered to collect primary data from reputed Jordanian accounting firms. During questionnaire development, the authors have been careful not to include any questions seeking confidential or personally identifiable information.

\subsection{Data Collection}

The questionnaire included six questions on corporate governance and four questions on the effectiveness of their AIS system. The questionnaire design followed popular Likert scale technique with a seven-point approach ranging from strongly disagree to strongly agree. Five hundred and twenty questionnaires have been distributed for data collection to 30 different accounting firms throughout Jordan. Four hundred and ninety-five questioned were returned after one month. Among them, thirteen were unengaged and therefore discarded. After the careful screening, there were 482 responses suitable for further analysis.

\subsection{Data Analysis Method}

The authors followed the footstep of previous researchers and chose SPSS software as the tool for statistical analysis. The authors acknowledge that the choice of analysis technique depends on the way the primary data has been collected, nature of the data and hypotheses to be tested. Some of the previous researchers applied t-tests, one-way ANOVA tests, cross-tabulation and multiple regression analyses. In this study, multiple regression analysis techniques has been applied to test the hypotheses.

\section{Analysis and Discussion}

The data gathered have been used to analyse and expand the concept and test the hypotheses developed in previously section. Before conducting detailed multivariate analysis, the reliability of the construct has been checked.

\subsection{Reliability}

Reliability analysis has been conducted to assess the internal consistency of the items predicting corporate governance.

The analysis illustrates that items achieved a Cronbach's Alpha score of 0.769 which satisfactorily meets the requirement of internal consistency (0.7) (Sekaran, 2003).

Table 1. Reliability Statistics

\begin{tabular}{ll}
\hline Cronbach's Alpha & $\mathrm{N}$ of Items \\
\hline .769 & 6 \\
\hline 82 Ease of Use and Effectiveness of AIS in Decision Making
\end{tabular}

8.2 Ease of Use and Effectiveness of AIS in Decision Making

Multiple regression analysis has been conducted to illustrate the influence of corporate governance on ease of use and effectiveness of account information system (AIS) in decision making. It has been hypotised that Management's data driven approach in decision making is likely to better utilise the merits of AIS system. Management's intention and enthusiasm regarding strategic data-driven decision making makes the best use of AIS and eventually improves the system's usability and makes it user-friendly. To implement an effective and user-friendly system, it needs to be governed by subject matter experts who understand and appreciates the system's capability and potentials. Therefore, it has been hypotised that the system must be monitored by a well-organized committee.

The following table shows the model summary. The table shows that the predictors i.e. 'data driven approach in decision making' and 'monitoring and control by relevant SMEs' can statistically explain up to $5.5 \%\left(\mathrm{R}^{2}\right)$ variability in 'ease of use and effectiveness of AIS in decision making'.

Table 2. Model Summary (AIS is easy to use and effective for decision making)

\begin{tabular}{lllll}
\hline Model & $\mathrm{R}$ & $\mathrm{R}$ Square & Adjusted R Square & Std. Error of the Estimate \\
\hline Regression & 0.235 & .055 & .051 & 1.749 \\
\hline
\end{tabular}

Predictors: (Constant), Management Practices data driven approach in decision making, Audit Committee oversees and monitors accounting and internal control and auditing activities

The following ANOVA table illustrates that the model is statistically significant $(\mathrm{p}<0.05)$ and capable of explaining the relationships between predicted variable i.e. 'ease of use and effectiveness of AIS in decision making' and predictors i.e. 'data driven approach in decision making' and 'monitoring and control by relevant SMEs'. 
Table 3. ANOVA (AIS is easy to use and effective for decision making)

\begin{tabular}{llllll}
\hline Model & Sum of Squares & Df & Mean Square & F & Sig. \\
\hline Regression & 85.783 & 2 & 42.891 & 14.017 & .000 \\
Residual & 1465.736 & 479 & 3.060 & & \\
Total & 1551.519 & 481 & & & \\
\hline
\end{tabular}

Dependent Variable: AIS is easy to use and effective for decision making

Predictors: (Constant), Management Practices data driven approach in decision making, Audit Committee oversees and monitors accounting and internal control and auditing activities

Table 4 below illustrates the relation between the predictors and predicted variable. The analysis shows that management intention to practices data driven approach in decision making $(\mathrm{p}<0.05)$ and SME-driven and controlled audit and accounting practice $(\mathrm{p}<0.05)$ has a significant influence on effectiveness and ease of use of accounting information system.

The analysis shows that 'data driven approach in decision making' and 'monitoring and control by relevant SMEs' do statistically influence 'ease of use and effectiveness of AIS in decision making' and therefore, we cannot reject the hypothesis 1 and 2 .

The model can be expressed by the following regression equation.

AIS is easy to use and effective for decision making $=3.544+0.195$ (Management practices data driven approach in decision making) +0.091 (Audit Committee oversees and monitors accounting and internal control and auditing activities) $+\varepsilon$

Table 4. Coefficients (AIS is easy to use and effective for decision making)

\begin{tabular}{|c|c|c|c|c|c|}
\hline \multirow[b]{2}{*}{ Model } & \multicolumn{2}{|c|}{ Unstandardized Coefficients } & $\begin{array}{l}\text { Standardized } \\
\text { Coefficients }\end{array}$ & \multirow[b]{2}{*}{$\mathrm{t}$} & \multirow[b]{2}{*}{ Sig. } \\
\hline & $\mathrm{B}$ & Std. Error & Beta & & \\
\hline (Constant) & 3.544 & .215 & & 16.472 & .000 \\
\hline $\begin{array}{l}\text { Management practices data driven approach in } \\
\text { decision making }\end{array}$ & .195 & .047 & .191 & 4.132 & .000 \\
\hline $\begin{array}{l}\text { Audit Committee oversees and monitors } \\
\text { accounting and internal control and auditing } \\
\text { activities }\end{array}$ & .091 & .044 & .096 & 2.077 & .038 \\
\hline
\end{tabular}

Dependent Variable: AIS is easy to use and effective for decision making

\subsection{Effective Security and Management of AIS}

The following section analyses how the corporate governance factors influence the security and management of AIS. the model summary illustrates that $19 \%$ of the variability in security and management of AIS is being explained by corporate governance factors such as 'All members of the Audit Committee have knowledge and experience in finance and accounting', 'Leadership team has clear vision, it is shared and aligned with business goals' and 'Management practices KPI based evaluation'.

Table 5. Model Summary (AIS is secured and well managed)

\begin{tabular}{|c|c|c|c|c|c|}
\hline Model & $\mathrm{R}$ & R Square & Adjusted R Square & \multicolumn{2}{|c|}{ Std. Error of the Estimate } \\
\hline Regression & 0.435 & .190 & .185 & \multicolumn{2}{|l|}{1.367} \\
\hline \multicolumn{6}{|c|}{$\begin{array}{l}\text { Predictors: (Constant), All members of the Audit Committee have knowledge and experience in finance and } \\
\text { accounting, Leadership team has clear vision, it is shared and aligned with business goals, Management practices } \\
\text { KPI based evaluation }\end{array}$} \\
\hline \multicolumn{6}{|c|}{$\begin{array}{l}\text { Table } 6 \text { below shows that the model has sufficient capacity }(\mathrm{p}<0.05) \text { to explain the predictor predicted } \\
\text { relationships. }\end{array}$} \\
\hline \multicolumn{6}{|c|}{ Table 6. ANOVA (AIS is secured and well managed) } \\
\hline Model & Sum & ares & Mean Square & $\mathrm{F}$ & Sig. \\
\hline Regression & 208. & & 69.610 & 37.275 & .000 \\
\hline Residual & 892. & & 1.867 & & \\
\hline Total & 110 & & 481 & & \\
\hline
\end{tabular}

Dependent Variable: AIS is secured and well managed

Predictors: (Constant), All members of the Audit Committee have knowledge and experience in finance and accounting, Leadership team has clear vision, it is shared and aligned with business goals, Management practices KPI based evaluation. 
The coefficient table below shows that governance of financial and accounting issue by a knowledgeable and experienced committee positively influences the security and management of AIS system $(\beta=0.291, p<0.05)$. The analysis shows that leadership teams' vision, its translation and it's alignment with business goals positively influence the security and management of AIS system $(\beta=0.2, p<0.05)$. The KPI based performance evaluation also significantly influence the effectiveness of AIS $(\beta=0.103, p<0.05)$. The analysis provides enough evidence to not reject hypothesis 3, 4 and 5 .

The model can be expressed by the following regression equation.

AIS is secured and well managed $=2.146+0.291$ (All members of the Audit Committee have knowledge and experience in finance and accounting) +0.200 (Leadership team has clear vision, it is shared and aligned with business goals) +0.103 (Management practices KPI based evaluation) $+\varepsilon$

Table 7. Coefficients (AIS is secured and well managed)

\begin{tabular}{|c|c|c|c|c|c|}
\hline \multirow[b]{2}{*}{ Model } & \multicolumn{2}{|c|}{$\begin{array}{l}\text { Unstandardized } \\
\text { Coefficients }\end{array}$} & \multicolumn{3}{|l|}{$\begin{array}{l}\text { Standardized } \\
\text { Coefficients }\end{array}$} \\
\hline & $\mathrm{B}$ & Std. Error & Beta & $\mathrm{t}$ & Sig. \\
\hline (Constant) & 2.146 & .317 & & 6.776 & .000 \\
\hline $\begin{array}{l}\text { All members of the Audit Committee have knowledge } \\
\text { and experience in finance and accounting }\end{array}$ & .291 & .039 & .313 & 7.437 & .000 \\
\hline $\begin{array}{l}\text { Leadership team has clear vision, it is shared and aligned } \\
\text { with business goals }\end{array}$ & .200 & .043 & .202 & 4.696 & .000 \\
\hline Management practices KPI based evaluation & .103 & .045 & .097 & 2.279 & .023 \\
\hline
\end{tabular}

\subsection{Usability and Importance of AIS for Departmental Delivery and Performance Evaluation}

The following analysis illustrates the influence of 'practice of KPI based evaluation' and 'SME-driven accounting and internal control' on 'usability and importance of AIS for departmental delivery and performance evaluation'. Model summary illustrates that the predictors explain 3.4\% $\left(\mathrm{R}^{2}\right)$ variability in the dependent variable i.e. usability and importance of AIS for departmental delivery and performance evaluation.

Table 8. Model Summary (All departments can use the information and it indeed is vital for their delivery and performance evaluation)

\begin{tabular}{|c|c|c|c|c|c|}
\hline Model & $\mathrm{R}$ & R Square & Adjusted R Square & \multicolumn{2}{|c|}{ Std. Error of the Estimate } \\
\hline Regression & 0.185 & .034 & .030 & 1.719 & \\
\hline \multicolumn{6}{|c|}{$\begin{array}{l}\text { Predictors: (Constant), Management Practices KPI based evaluation, Audit Committee oversees and monitors } \\
\text { accounting and internal control and auditing activities }\end{array}$} \\
\hline \multicolumn{6}{|c|}{ Table 9 below provides enough evidence that the model can explain the hypothesised relations $(\mathrm{p}<0.05)$. } \\
\hline \multicolumn{6}{|c|}{$\begin{array}{l}\text { Table 9. ANOVA (All departments can use the information and it indeed is vital for their delivery and } \\
\text { performance evaluation) }\end{array}$} \\
\hline Model & Sun & uares & Mean Square & $\mathrm{F}$ & Sig. \\
\hline Regre & & & 25.149 & 8.508 & .000 \\
\hline Residual & & & 2.956 & & \\
\hline Total & 146 & & 481 & & \\
\hline
\end{tabular}

Dependent Variable: All departments can use the information and it indeed is vital for their delivery and performance evaluation

Predictors: (Constant), Management Practices KPI based evaluation, Audit Committee oversees and monitors accounting and internal control and auditing activities

The following table illustrates the statistical significance of the hypnotised relationships. The analysis shows that, the practice of KPI based evaluation $(\beta=0.191, \mathrm{p}<0.05)$ and SME-driven system $(\beta=0.082, \mathrm{p}<0.05)$ have a significant influence on the usability of AIS information and its effectiveness for delivery and performance. The analysis provides enough evidence to retain hypothesis 6 and 7.

The model can be expressed by the following regression equation.

All departments can use the information and it indeed is vital for their delivery and performance evaluation $=3.348$ +0.191 (Management practices KPI based evaluation) + 0.082 (Audit Committee oversees and monitors accounting and internal control and auditing activities) $+\varepsilon$ 
Table 10. Coefficients (All departments can use the information and it indeed is vital for their delivery and performance evaluation)

\begin{tabular}{|c|c|c|c|c|c|}
\hline \multirow[b]{2}{*}{ Model } & \multicolumn{2}{|c|}{$\begin{array}{l}\text { Unstandardized } \\
\text { Coefficients }\end{array}$} & \multicolumn{3}{|l|}{$\begin{array}{l}\text { Standardized } \\
\text { Coefficients }\end{array}$} \\
\hline & $\mathrm{B}$ & Std. Error & Beta & $\mathrm{t}$ & Sig. \\
\hline (Constant) & 3.348 & .315 & & 10.622 & .000 \\
\hline Management practices KPI based evaluation & .191 & .055 & .157 & 3.483 & .001 \\
\hline $\begin{array}{l}\text { Audit Committee oversees and monitors accounting and } \\
\text { internal control and auditing activities }\end{array}$ & .082 & .041 & .089 & 1.981 & .048 \\
\hline
\end{tabular}

Dependent Variable: All departments can use the information and it indeed is vital for their delivery and performance evaluation

\subsection{Adequacy of Data Storage and Recall System of AIS and It's Alignment with Business Goal}

The model summary table shows that $14.1 \%$ of the variability in predicted factor is being explained by the model's predictors.

Table 11. Model Summary (AIS data storage and recall system is adequate and aligned with business goal)

\begin{tabular}{|c|c|c|c|c|c|}
\hline Model & $\mathrm{R}$ & R Square & Adjusted R Square & Std. Error of & \\
\hline Regression & 0.375 & .141 & .135 & 1.443 & \\
\hline \multicolumn{6}{|c|}{$\begin{array}{l}\text { Predictors: (Constant), Leadership team has clear vision, it is shared and aligned with business goals, All } \\
\text { members of the Audit Committee have knowledge and experience in finance and accounting, The board of } \\
\text { directors meet often to discuss strategies and policies (with information) }\end{array}$} \\
\hline \multicolumn{6}{|c|}{ The ANOVA table below shows that the model is significant with $\mathrm{p}<0.05$. } \\
\hline \multicolumn{6}{|c|}{ Table 12. ANOVA (AIS data storage and recall system is adequate and aligned with business goal) } \\
\hline Model & Sum & & Mean Square & $\mathrm{F}$ & Sig. \\
\hline Regression & 162. & & 54.279 & 26.079 & .000 \\
\hline Residual & 994.8 & & 2.081 & & \\
\hline Total & 1157 & & 481 & & \\
\hline
\end{tabular}

Dependent Variable: AIS data storage and recall system is adequate and aligned with business goal

Predictors: (Constant), Leadership team has clear vision, it is shared and aligned with business goals, All members of the Audit Committee have knowledge and experience in finance and accounting, The board of directors meet often to discuss strategies and policies (with information)

Table 13 below shows that transparency, translation and alignment of vision, significantly influences adequacy of storage and recall system of AIS data and it's alignment with business goals $(\beta=0.274, p<0.05)$. The knowledge and experience of governing committee are also vital for effective storage and recall of AIS data and it's alignment with business goals $(\beta=0.130, \mathrm{p}<0.05)$. The analysis further illustrated that effective collaboration and strategic discussion about company policies can positively influence effective storage and recall of AIS data and it's alignment with business goals $(\beta=0.096, p<0.05)$. Based on the above evidence hypothesis 8,9 and 10 cannot be rejected.

The model can be expressed by the following regression equation.

AIS data storage and recall system is adequate and aligned with business goal $=2.098+0.274$ (Leadership team has clear vision, it is shared and aligned with business goals) + 0.130 (All members of the Audit Committee have knowledge and experience in finance and accounting) +0.096 (The board of directors meet often to discuss strategies and policies (with information)) $+\varepsilon$

Table 13. Coefficients (AIS data storage and recall system is adequate and aligned with business goal)

\begin{tabular}{|c|c|c|c|c|c|}
\hline \multirow[b]{2}{*}{ Model } & \multicolumn{2}{|c|}{$\begin{array}{l}\text { Unstandardized } \\
\text { Coefficients }\end{array}$} & \multicolumn{3}{|l|}{$\begin{array}{l}\text { Standardized } \\
\text { Coefficients }\end{array}$} \\
\hline & B & Std. Error & Beta & $\mathrm{t}$ & Sig. \\
\hline (Constant) & 2.098 & .303 & & 6.923 & .000 \\
\hline $\begin{array}{l}\text { Leadership team has clear vision, it is shared and aligned } \\
\text { with business goals }\end{array}$ & .274 & .046 & .270 & 6.005 & .000 \\
\hline $\begin{array}{l}\text { All members of the Audit Committee have knowledge } \\
\text { and experience in finance and accounting }\end{array}$ & .130 & .041 & .136 & 3.147 & .002 \\
\hline $\begin{array}{l}\text { The board of directors meet often to discuss strategies and } \\
\text { policies (with information) }\end{array}$ & .096 & .038 & .114 & 2.539 & .011 \\
\hline
\end{tabular}

Dependent Variable: AIS data storage and recall system is adequate and aligned with business goal 


\section{Hypothesis testing}

The following table shows the status of hypothesis testing from the analysis of data gathered.

Table 14. Hypothesis testing results

\begin{tabular}{|c|c|}
\hline Hypotheses & Status \\
\hline $\begin{array}{l}\text { H1: Management's practice of data-driven approach in decision making influences ease of use and } \\
\text { effectiveness of AIS in decision making }\end{array}$ & Not rejected \\
\hline $\begin{array}{l}\text { H2: SME governed accounting system influences ease of use and effectiveness of AIS in decision } \\
\text { making }\end{array}$ & Not rejected \\
\hline $\begin{array}{l}\text { H3: Governing committee's knowledge and experience in finance and accounting influences } \\
\text { effective security and management of AIS }\end{array}$ & Not rejected \\
\hline $\begin{array}{l}\text { H4: Leadership teams' vision, it's translation and alignment with business goals influences effective } \\
\text { security and management of AIS }\end{array}$ & Not rejected \\
\hline H5: KPI based performance evaluation influences effective security and management of AIS & Not rejected \\
\hline $\begin{array}{l}\text { H6: Management's practice of KPI based evaluation influences usability and importance of AIS for } \\
\text { departmental delivery and performance evaluation }\end{array}$ & Not rejected \\
\hline $\begin{array}{l}\text { H7: SME governed accounting system influences usability and importance of AIS for departmental } \\
\text { delivery and performance evaluation }\end{array}$ & Not rejected \\
\hline $\begin{array}{l}\text { H8: Leadership team's vision, translation and their alignment with business goals influences effective } \\
\text { storage and recall system of AIS data and it's alignment with business goals }\end{array}$ & Not rejected \\
\hline $\begin{array}{l}\text { H9: Governing committee's knowledge and experience in finance and accounting influences storage } \\
\text { and recall system of AIS data and it's alignment with business goals }\end{array}$ & Not rejected \\
\hline $\begin{array}{l}\text { H10: Effective collaboration and strategic discussion about company policies influence storage and } \\
\text { recall system of AIS data and it's alignment with business goals }\end{array}$ & Not rejected \\
\hline
\end{tabular}

\section{Conclusion}

The study focused on reestablishing the empirical concept of corporate governance influencing the effectiveness of accounting information system. The topic has been explored with secondary data in to see how the theory holds for Jordanian accounting firms. Authors considered Jordanian industrial companies listed in the Amman Financial Market. After an extensive review of the literature and previous researchers on similar topics, authors developed a number of hypotheses to be tested against the data gathered. Using proper statistical analysis technique the data have been analysed to draw conclusions. The analysis provided valuable insights into the vital role played by company's corporate governance approach and it's influence on the accounting information system (AIS). Analysis showed that, if the management adopts a data-driven approach to make strategic decisions, AIS can be a vital tool to support the purpose by providing structured real-time information and accelerate performance. Company's account information system is likely to be an user-friendly and comprehensive mean if it is governed by subject matter experts.

Analysis showed that the governing committee must have proper knowledge and experience with finance and accounting methodologies to ensure that AIS is secure and well managed and can aid decision making efficiently. The leadership team must create a clear vision and ASMART goals to make the best use of a secured and well managed AIS. The practice of KPI based performance evaluation creates a need for efficient AIS and therefore positively influence the development of AIS that would help various departments and accelerate their performance by steering them in the right direction. To rip the benefit of the system it should be governed by a committee who have hands on experience with finance and accounting so that they can translate the needs of various department's needs into system features. The analysis shows that the storage and recall system of AIS data and it's alignment with business goals depends on how the leaders understand and can demonstrate the company's vision and set ASMART goals to achieve targets. The leaders should have effective communication, collaboration and strategic discussion about company policies so that the AIS can be structured to deliver results.

\section{References}

Al-jazi, O. H. (2007). Corporate Governance in Jordan. Retrieved from: http://www.aljazylaw.comlarabiclpdfka/kamat/alsherkat2.pdf

Almasarwah, A. (2015). Earnings management and its relationship with corporate governance mechanisms in Jordanian industrial firms.

Bolon, M. (1998). Factors influencing the alignment of accounting information systems in small and medium sized Malaysian manufacturing firms.

Borthick, A. F., \& Clark, R. L. (1990). Making accounting information systems work: An empirical investigation of the creative thinking paradigm. Journal of Information Systems, 4(3), 48-62.

Bouwens, J., \& Abernethy, M. A. (2000). The consequences of customization on management accounting system 
design. Accounting, Organizations and Society, 25(3), 221-241.

https://doi.org/10.1016/S0361-3682(99)00043-4

Chenhall. (2003). Management control systems design within its organisational context: findings from contingency-based research and directions for the future. Accounting, Organizations and Society, 28, 127-168. https://doi.org/10.1016/S0361-3682(01)00027-7

Curtis, G. (1995). Business information systems: Analysis, design and practice. Wokingham: Addison-Wesley Publishing Company.

El Louadi, M. (1998). The relationship among organization structure, information technology and information processing in small Canadian firms. Canadian Journal of Administrative Sciences, 15(2), 180-199. https://doi.org/10.1111/j.1936-4490.1998.tb00161.x

Financial Accounting Standards Board (FASB). (1980). Qualitative characteristics of accounting information. Statement of Financial Accounting Concepts No. 2, Norwalk, CT: FASB.

Gordon, L. A., \& Sellers, F. E. (1984). Accounting and budgeting systems: The issue of congruency. Journal of Accounting and Public Policy, 3(4), 259-292. https://doi.org/10.1016/0278-4254(84)90023-1

Hunton, J. E. (2002). Blending information and communication technology with accounting research. Accounting Horizons, 16(1), 55-67. https://doi.org/10.2308/acch.2002.16.1.55

Ittner, C. D., \& Larcker, D. F. (2003).Coming Up Short on Nonfinancial Performance Measurement. Harvard Business Review, 81(11), 88-95.

Kadous, K., Koonce, L., \& Thayer, J. M. (2012). Do financial statement users judge relevance based on properties of reliability? The Accounting Review, 87(4), 1335-1356, American Accounting Association. https://doi.org/10.2308/accr-50157

Langfield-Smith, K. (1997). Management control systems and strategy: a critical review. Accounting, Organizations and Society, 22, 207-232. https://doi.org/10.1016/S0361-3682(95)00040-2

Marashdeh, Z. (2014). The Effect of Corporate Governance on Firm Performance in Jordan.

Moscove, S. A., \& Simkin, M. G. (1984). Accounting information systems. New York, NY: John Wiley \& Sons, Inc.

Nicolaou, A. I. (2000). A Contingency Model of Perceived Effectiveness in Accounting. Information Systems: Organizational Coordination and Control Effects.

Ponemon, L. A., \& Nagoda, R. J. (1990). Perceptual variation and the implementation of accounting information systems: An Empirical investigation. Journal of Information System, 4(2), 1-14.

Rahman, M., \& Halladay, M. (1988). Accounting information systems: Principles, applications and future directions. New Jersey: Prentice Hall.

Rankin, M., Stanton, P., McGowan, S., Ferlauto, K., \& Tilling, M. (2012). Contemporary issues in accounting (1st Ed.). Australia: John Wiley \& Sons Australia, Ltd.

Romney, M. B., \& Steinbart, P. J. (2006). Accounting Information Systems, 10th Edition.

Sekaran, U. (2003). Research methods for business s (4th ed.). Hoboken, NJ: John Wiley \& Sons.

Watts, H. (1999). A Conceptual Framework to Financial Reports and Internal Audits, 20, 753-778.

Wilkinson, J. W. (1993). Accounting information systems: Essential concepts and applications. Second Edition. New York: John Wiley \& Sons Inc.

Wilkinson, J. W., Cerullo, M. J., Raval, V., \& Wong-On-Wing, B. (2000). Accounting information systems: Essential concepts and applications. New York: John Wiley and Sons.

\section{Copyrights}

Copyright for this article is retained by the author(s), with first publication rights granted to the journal.

This is an open-access article distributed under the terms and conditions of the Creative Commons Attribution license (http://creativecommons.org/licenses/by/4.0/). 